\title{
UNITY IN DIVERSITY: MOVING INDONESIAN THEATER, FILM, AND TELEVISION FORWARD
}

\author{
Eka Dimitri Sitorus ${ }^{1}$ \\ ${ }^{1}$ Sakti Actor Studio; dimitristrossky@hotmail.com
}

\begin{abstract}
Doc Archive
Submited: 06-09-2020

Accepted: 21-12-2020

Published: 31-01-2021

Keywords

performing arts; drama;

theatre; cultural policy

Abstract

The purpose of this article is to show how Indonesia has experienced a tremendous change in its approach to acting in the last 20 years, but it has not been for the better. The modern era of film and television has led to a misleading perception among the Indonesian people regarding the art of "acting," thereby resulting in an unfavorable attitude toward the craft. This misleading perception stems from the effect of traditional Indonesian theater to its modern counterpart without any adjustments to cater to the millennial generation of Indonesians. The paper explores the roots of this misleading perception. It starts with the problem of applying Indonesian cultural policy, catering to such diverse artistic expressions in Indonesia, educating the artists, all the way to providing the specific educational infrastructure for the arts. The article provides examples of past theater and film productions to point out the problems of modern versus traditional acting styles, the challenges of translations of classic and contemporary western plays into the Indonesian language, the difficulties to apply such rigid interpretations by prominent Indonesian writer to contemporary Indonesian acting styles. The article shows that only by improving and implementing sound Indonesian cultural policy, developing and managing specific educational infrastructure for the arts, and creating a new acting method or re-considering the pre-existing ones, the Indonesian theatre, film, and television will be able to move forward.
\end{abstract}

\section{Introduction}

Although Indonesia has experienced a tremendous change in its approach to acting in the last 20 years, it has not been for the better. The modern era of film and television has led to a misleading perception among the Indonesian people regarding the art of "acting," thereby resulting in an unfavorable attitude toward the craft. First, the lack of understanding about the method among the Indonesian theatre and film community contributes to the above. Second, the various acting styles created by prominent Indonesian teachers separate the art of acting in theater and film and television. It appears as if there are two different approaches to acting: east versus west. Historically, acting styles in theater follow the traditional Indonesian "dance drama" format where expressions are exaggerated, and gestures are grandiose. Moreover, actors deliver their dialog as if they are singing, and the dancers in the Javanese "Wayang Orang" precede their speeches with gestures or moves in slow motion along with using physical expressions before delivering their lines. The actors in the traditional West Sumatran theater, the "Randai", choreograph dance moves before uttering their dialogs. The set in the Batavian traditional theater uses two mystical doors upstage for the actors to enter and exit, and there is a lamp post at the center of the stage. When performing new plays, modern Indonesian theater has based its approach on the following three traditional dance dramas: comedies using the "Lenong", while the tragedies using the Wayang Orang and the Randai.

Modern Indonesian film and television follow this eastern tradition and try to make it applicable by somehow adjusting it without learning the method. Furthermore, new film and television directors learn through experience handed down orally from the older generations. 
They combine the eastern approaches to acting by learning the western ones in bits and chunks, thereby creating sporadic and unnatural expressions. There are times when the actors look natural, but moments later, in close-ups shots, their emotions become exaggerated and worse than the grand gestures found in the theater.

The Department of Education and Culture's stance serves to complicate our discussion further. According to the ministry, plays must use proper Indonesian language (Bahasa Indonesia) and actors should act accordingly. As an unfortunate result, actors find themselves moving around, yapping like robots. Most Indonesian people, from the very beginning, use their respective tribal languages. They only learn Indonesian language at school and often only to read or listen to the news. They never use proper Bahasa Indonesia in everyday conversation because it sounds alien to them. Moreover, people daily use a combination of their tribal and Indonesian language. In Jakarta, for example, the Batavian use Betawi (their tribe language), which is a combination of Arabic, East Indian, Chinese, and Indonesian. If we unified these acting approaches to create one cultural expression, Bahasa Indonesia, we would never be able to relate to a story.

Consider the film "Pendekar Tongkat Emas" (The Golden Cane Warrior). All the lines in this movie use proper Bahasa Indonesia. However, by dignifying the language, the actors suffer greatly. They speak in a hoarse, deep voice as if they are not using their breath at all. Consequently, the acting and dialog become unnatural. On the other hand, in the Netflix original film "Soekarno", the actors use the Javanese tribe language with Indonesian subtitles and yet sound more natural, believable, and subtle. Soekarno contains all the elements of traditional theater, such as a melodical delivery of the dialog, almost like singing. The actors also pause frequently and insert various gestures before uttering the next line. At the beginning of the story, we learn that Soekarno (character) was often sick. To avoid this curse in the future, the leader of his family and relatives decided to change his name from Kusno to Soekarno. In the meeting, plenty of dialogs are delivered eloquently by the tribe leader. When giving their opinions, the relatives deliver their dialogs according to their status within the tribe. It is their custom to apologize before stating their views on the matter. This scene resembles the
Wayang Orang, but all of us modern Indonesians understand the story.

How can we retain such expressions that are traditional yet honest as well as gestures that are eloquent yet sincere and theatrical yet subtle using Bahasa Indonesia? Most western theaters model their dramatic language on real-life conversations among people. It is unlike the traditional Indonesian theater, where dramatic writing is appreciated more for its sound than for its meaning.

We do understand, however, that when one watches a western theater performance, one also must consider the differences between real conversation and dramatic dialog. Furthermore, dramatic language is ultimately always constructed or "made up," and it often serves several purposes. In the story-world of a play, language can assume all the pragmatic functions. We find it in real-life conversations to ensure mutual understanding and convey information, to persuade or influence others, and relate to one's experiences and signal emotions. However, dramatic language is often rhetorical and poetic: language is used in ways that differ from standard usage to draw attention to its artistic nature.

Various forms of utterance available for drama, such as monolog, dialog, or soliloquy, are dramatic languages. They also exist in the traditional Indonesian theater. However, monolog in a western play is delivered when one character speaks by himself or herself for a period (longer than a dialog) or to other characters. In traditional Indonesian theater, monolog and soliloquy are presented through chanting, melodically delivered by a priest. For example, in Randai, a group of dancers stops amids their routine and begins delivering a monolog or soliloquy, chanting in their ethnic language and then starting to dance again, before uttering another monolog or soliloquy. In Randai, not many dialogs are involved between the dancers, who are also the actors; the performance is just a series of dances and monologs. Although singing is also a part of Randai, they use it between the acts to narrate the play.

One of Indonesia's foremost traditional theater forms is Randai. However, only the Padangnese tribe understands the meaning of the dramatic language and its sounds. For other ethnic groups in Indonesia, Randai is a confusing dance drama to watch. Only if we create a specific method, maybe other tribes in Indonesia can enjoy Randai. 


\section{The Problems of Translation}

To compare the dramatic language in traditional Indonesian theatre, we need to consider a Shakespearean play. In the western world, theater experts create methods to modernize Shakespeare so that the modern English-speaking world can relate. Actors learn to use the "iambic pentameter" so that it doesn't sound like they are chanting the lines.

Let us consider the famous soliloquy from "Hamlet". In Indonesian, the monolog is translated by Trisno Soemardjo (1950), can be seen in Table 1.

Table 1. Soliloquy from Hamlet and its Indonesian translation

\begin{tabular}{|c|c|}
\hline $\begin{array}{l}\text { Shakespeare. Hamlet, III, 1: } \\
56-88\end{array}$ & $\begin{array}{l}\text { Translated by Trisno } \\
\text { Soemardjo }\end{array}$ \\
\hline $\begin{array}{l}\text { To be, or not to be, that is } \\
\text { the question: } \\
\text { Whether 'tis nobler in the } \\
\text { mind to suffer } \\
\text { The slings and arrows of } \\
\text { outrageous fortune, } \\
\text { Or to take arms against a sea } \\
\text { of troubles } \\
\text { And by opposing end them. } \\
\text { To die - to sleep, } \\
\text { No more; and by a sleep to } \\
\text { say we end } \\
\text { The heart-ache and the } \\
\text { thousand natural shocks } \\
\text { That flesh is heir to: 'tis a } \\
\text { consummation } \\
\text { Devoutly to be wish'd. To } \\
\text { die, to sleep; } \\
\text { To sleep, perchance to } \\
\text { dream - ay, there's the rub: } \\
\text { For in that sleep of death } \\
\text { what dreams may come, } \\
\text { When we have shuffled off } \\
\text { this mortal coil, } \\
\text { Must give us pause - there's } \\
\text { the respect } \\
\text { That makes calamity of so } \\
\text { long life. } \\
\text { Thus, conscience does make } \\
\text { cowards of us all, } \\
\text { And thus the native hue of } \\
\text { resolution } \\
\text { Is sicklied o'er with the pale } \\
\text { cast of thought, } \\
\text { And enterprises of great } \\
\text { pitch and moment } \\
\text { With this regard their } \\
\text { currents turn awry } \\
\text { And lose the name of action. } \\
\text { Soft you now, } \\
\text { The fair Ophelia! Nymph, in } \\
\text { thy orisons } \\
\text { Be all my sins remember'd. }\end{array}$ & $\begin{array}{l}\text { Ada atau tiada, itu soalnya. } \\
\text { Mana yang lebih mulia: } \\
\text { menerima dengan rela } \\
\text { Panah dan busur nasib buruk } \\
\text { yang ganas } \\
\text { Atau berperang melawan } \\
\text { lautan bencana, } \\
\text { Dan menentang, lalu } \\
\text { mengakhirnya? Mati, tidur... } \\
\text { Dan kalau dengan tidur kita } \\
\text { sudahi derita hati } \\
\text { Dan seribu sengsara yang } \\
\text { menjadi warisan insani, } \\
\text { Maka hendaknya kita akhiri } \\
\text { dengan doa suci. } \\
\text { Tapi kalau tidur - ada } \\
\text { mimpi. Nah, } \\
\text { perintangnya. } \\
\text { Karena mungkin yang kita } \\
\text { impikan dalam tidur maut } \\
\text { itu, lu budah lepas dari } \\
\text { Kalau sudah } \\
\text { kekacauan hidup ini } \\
\text { Akan menghambat kita. } \\
\text { Pengamatan itu } \\
\text { Menyebabkan azab derita } \\
\text { panjang umurnya. } \\
\text { Sebab siapa betah keonaran } \\
\text { dan kekejian zaman, } \\
\text { Penindasan, penghinaan, } \\
\text { kesombongan, } \\
\text { Asmara yang gagal, } \\
\text { keadilan yang terlambat, } \\
\text { Kekuasaan yang congkak, } \\
\text { dan penistaan, } \\
\text { Kalau dengan satu tikaman } \\
\text { pisau saja, } \\
\text { Orang dapat kedamaian? } \\
\text { Tapi siapa yang mau } \\
\text { memikul, } \\
\text { Menggerutu, dan menderita } \\
\text { dibawah beban } \\
\text { sengsara, hidup } \\
\text { Kalau tak takut pada sesuatu } \\
\text { sesudah mati, } \\
\text { Pada dunia yang belum }\end{array}$ \\
\hline
\end{tabular}

\begin{tabular}{ll}
\hline pernah dijelajahi, dari mana \\
musafir \\
Tak pernah kembali dengan \\
selamat. \\
Pasti dia akan merubah \\
kehendaknya dan lebih suka \\
menderita, \\
Daripada Lari menuju apa \\
yang belum dikenalnya? \\
Pertimbangan membuat kita \\
semua menjadi pengecut. \\
Dan niat untuk resolusi yang \\
cepat menjadi lesu karena \\
takut. \\
Hingga tekat yang besar \\
nilainya, \\
pertimbangan, \\
Berbelok haluan hingga \\
tidak dapat dinamakan \\
perbuatan. \\
\hline
\end{tabular}

First, we would need 198 words of Bahasa Indonesia to translate 179 words of the original English version, which means Indonesian actors need to give other expressions (more "telling" than "showing" in their actions) to certain English words. Shakespeare also uses blank verse (iambic pentameter), which means that the actor speaks with a consistent meter. In the Indonesian translation, the meter is inconsistent. Second, blank verse is a necessary tool for an actor to create his character since it positions their status in society. In this case, it represents the character as noble and a member of a high culture society. In Indonesian translation, we can say goodbye to Hamlet's nobility and high-cultured position. Now, modern western actors learn the importance of blank verse because it helps them understand not only the character's social status but also his or her inner conflict.

Finally, although the sound of blank verse is like "singsong," western actors study the monolog and train in a specific acting method (mostly the Stanislavski system) to deliver this monolog as realistically as possible. Moreover, words, modulation or tone, and the actor's physical expressions, including their gestures and blocking, are combined precisely so that modern audiences understand the meaning of the monolog or at least one interpretation of its meaning. Hamlet's soliloquy reveals his inner conflict. Audiences understand that Hamlet are confused between taking action and remaining passive. The fact is, Hamlet is an almost depressing character. Thinking about life's pain, death, and suicidal thoughts. Hamlet shows itself as a melancholy person. At the same time, speech from Hamlet is profound and philosophical, and thus, He seems thoughtful and intellectual. In the 
Indonesian translation, Hamlet appears indecisive because much of the word choices and the sound is lost or transformed with the translated monolog.

When we translate a play from the original language, we lose most of its meaning, including the beauty of the words chosen by the playwright. Although the Indonesian translation of Hamlet tries to retain the beauty of the words, it sounds "unreal" to the Indonesian audience since they never use such language in their everyday conversation. Moreover, modern Indonesian actors deliver this monolog by emphasizing the sound more than its meaning, making it like "singsong." Since they have no training to make it realistic, the audience don't understand the story of the play. This presentation of Shakespearean plays sounds almost like the actor/dancers in Randai. Although some modern Indonesian actors have also studied the Stanislavski system, they never learned a specific acting method for Shakespearean plays.

Another form of English dramatic language is asides, where a character speaks secretively to other characters or the audience. Asides are created so that actors can relate to the audience and involve them in the play. Indonesian theater never uses asides. Other forms of English dramatic language are turn-allocation, stichomythia, and repartee. They are also challenging to apply, both to modern and traditional Indonesian theater.

Indonesian theater needs to modernize its traditional theater by translating plays that use tribe language into modern Bahasa Indonesia. As "made up" as the language may be, the current acting methods (as opposed to traditional techniques found in many kinds of Indonesian performance genres) will be able to adjust to it. Furthermore, many plays in Wayang Orang and Randai depict universal and everlasting stories. The message is valid to the traditional Indonesian people who can speak the tribe language as well as to modern Indonesians who know Bahasa.

\section{The Problem of Applying the Western Acting Method}

Indonesian dramatists must create a unifying method to tackle the challenges in making traditional theater enjoyable to the modern audience or members of the other tribes besides the Javanese or the Padangnese. Through a new or modified western acting method and a more lenient translation as opposed to rigid grammatical structure, the audience will appreciate the physical expressions, gestures, and moves in Wayang Orang or the chanting in Randai.

In 1989, I directed The Bacchae by Euripides for my master's degree thesis, incorporating The "Kecak Dance" from Bali. I asked William Arrowsmith, a prominent expert in Greek Tragedy, for his advice on the Bacchae because I wanted to create Dionysus as an American Tourist who came to Bali and ruined their way of life. Although he did not agree with my interpretation, after asking permission from my advisers, I continued with the production.

In my production, Dionysus gained many Balinese followers, who were suddenly in a trance at the side of him. Everywhere he went, women followed, including Pentheus's mother. Pentheus retaliated, and Dionysus ruined him. However, in my production, the Kecak is a trance-inducing exorcism dance, but since Dionysus is the God of Wine, I interpreted "in a trance" as "being drunk." Moreover, the dancers are mostly men who only wear loincloths while the upper parts of their bodies left bare. In my production, all the dancers are women (in 2006, modern interpretation of the Kecak incorporated women as the dancers).

Leo Stutzin (1989), The Modesto Bee arts editor, gave me the following review:

You are going to have an extraordinary experience, the god Dionysus promises the king Pentheus as "The Bacchae" hurtles toward a climax steeped in gore and fury.

The promise could have been made to his audiences by Eka Sitorus, director of the intense and color-filled production in Stanislaus State University's Studio Theater. In mounting the play, Sitorus grafted a personal and contemporary veneer onto one of the most ancient of Western dramas, written some 2,400 years ago by Euripides.

The effort is compelling and extraordinary - far beyond the commonplace - even if it is less than fully successful.

Sitorus, a native of Indonesia and graduate student at the Turlock school, has turned "The Bacchae" into a metaphoric vehicle for commenting on the irresistible invasion of Western values on the island cultures of the South Pacific. The resulting transformation cannot be called progress.

Sitorus' Dionysus appears as a glib, smirking tourist in shorts, sneakers, and gaudy shirt, adorned with postcard pictures of tropical beaches; his Pentheus is an effete and vain monarch bedecked in embroidered robe and gold-filigree crown.

Both radiate smugness, but the battle between their wills is no contest. Gods can out-muscle mere kings every time. But the underlying theme goes well beyond the suggestion that one onerous ruler has displaced the other.

While remaining true to Euripides' narrative, the play suggests that there are no winners dealing with allpowerful deities, whether those gods arrive with battleships or Big Macs. Resist, and you lose your head; acquiesce, and you lose your soul, your dignity, and 
your social order.

To give the drama an Indonesian flavor, Sitorus built his production around a text that inserts a handful of geographic references that would have been un-Greek to Euripides: Dionysus (Clay Everett) introduces himself with chipper good humor as a visitor "from the U.S. of A." Pentheus (Roger Reinitz) and others add references to Bali.

The Bacchae - eight women who have been swept into the exuberant revelry of Dionysian cult ritual - dress and dance in Balinese fashion. Everett brings his role a bright performance with unusual subtlety and depth. On the surface, he's the quintessential touristsalesman, radiating charm and cheerfulness. Beneath that surface, he's tough, determined, and capable of unspeakable horror.

As Pentheus, Reinitz is less persuasive, delivering the king's hollow threats in rhythms that seem mechanical rather than vacuous. In the play's most wrenching role, Karen Olsen descends from strength and stature to insane rage as Pentheus' mother, Agave. Stephanie Weber contributes an intriguing dimension as a messenger - with the look of a slightly demented bag lady - who observes the proceedings with a cynical eye and reads her grotesque tale as a dispatch from a newspaper.

The play presents two challenges that Sitorus and his student actors have not been able to master, however. One comes from the choral structure of Greek drama, and the need to generate power through a ritual form; the other is the need to give an exotic, South Pacific look to the participants.

Ritual resonances are decidedly foreign to Turlock; fresh, pale California actresses don't look Polynesian and don't seem comfortable with the sleek gestures of Balinese dance.

Noble Dinse designed the stunning set, whose centerpiece is an archway in the face of a demon with huge, open mouth and glowing eyes. Jeanette Farr and Tammy Hughes did the costumes, which reach glittering heights of Balinese opulence.

Jerry O'Donnell contributes a throbbing drum-beat that intensifies the play's ritual fervor.

Modern Indonesians would relate to this production. Dr. Douglas McDermott, one of professors at Cal State, asked me casually while he was walking down the hall to his office: "Are we that bad?" My answer was a compromising one: "There are two sides to the argument, Doug." He stopped and waited for me to explain further. "As a representative of Balinese's traditional believes, Pentheus is not deeply rooted. His believes are questionable." Doug didn't say anything and just walked away. No matter how radical the interpretation, we need to make some adjustments to the classic plays without ruining their central themes.

Stutzin mentioned that the production was "personal and contemporary," and it was "far beyond the commonplace." One of my personal, contemporary, and conventional interpretation is the set. In my production, Dionysus came to Goa Gajah (The Elephant Cave). The Goa Gajah is located on the cool western edge of Bedulu Village, six kilometers out of central Ubud in the districts of Gianyar, Bali. The set, designed by
Noble Dinse. He added two elephant statues on the left and right sides for the cave. The figures act as water fountains and flow throughout the play. The Goa Gajah is shown in Figure 1.

The Goa Gajah is everything but sexy. However, Indonesian prostitutes, male or female, use it as an expression to lure tourists by saying: "Welcome to my Goa Gajah," comparing the elephant's mouth to their vagina (or mouth, for the male).

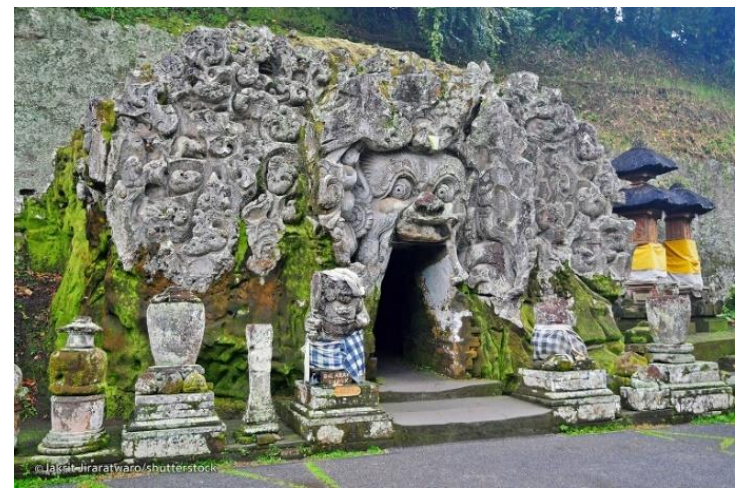

Figure 1. The Goa Gajah in Bali

One other personal interpretation is changing male dancers to female. As stated above, only in 2006, the Kecak incorporated women as dancers. To young tourists, Indonesian women are exotic. Their skin arouses sexual desire. We cannot deny that Bali is a paradise not only for the island's beauty, the beaches, and the rituals but also a place to express fully one's sexual desire.

Applying western acting into the Indonesian way of life requires plenty of sacrifices. We need to embrace a liberal approach to life as opposed to our conservative, even narrow-minded, view. Realistic acting is the core of the western approach to art, and Indonesians must learn to act naturally.

The challenge, according to Stutzin:

... comes from the choral structure of Greek drama, and the need to generate power through a ritual form; the other is the need to give an exotic, South Pacific look to the participants. Ritual resonances are decidedly foreign to Turlock; fresh, pale California actresses don't look Polynesian and don't seem comfortable with the sleek gestures of Balinese dance.

Stutzin's concerns regarding the ritual form of Greek drama in this production. The beat of the Indonesian dance movement is challenging to follow. The Kecak uses the pentatonic scale, which contrasts with the more familiar heptatonic. On the other hand, although Indonesian actors/dancers will not have any problems presenting the Kecak's sleek gestures, 
in my opinion, they don't have the training to express modern, truthful, and natural acting.

One example of production using Indonesian traditional dance drama, the Randai, is "Luck and Loss: Manandin's Gamble" by the University of Hawaii at Manoa. The production retained all the dance-drama, the music, the singing, and the martial arts. Unfortunately, keeping most of the dance drama without incorporating modern realistic acting into the performance can ruin it for the audience. Moreover, producing Randai for Randai's sake will make the audience, who is not Padangnese, confused. Therefore, for that audience, the production must make some adjustments; maybe not the music and/or the dance, but the acting styles. Since hand gestures are expressions of a character's inner conflict, in this production, all the actors use their gestures to "tell," when in fact, they should use them to "show" the story.

Accordingly, we must explore all western methods and create one that applies to Indonesian traditional acting styles. We don't have any problems involving the Stanislavski method of acting into the Lenong since it is modern enough. The Lenong has similar approaches to the comedy of "Laurel and Hardy". They use verbal banters that most Batavians use in their everyday conversations. However, in other Indonesian traditional theaters, the manner is entirely different. It is quite formal compared to the natural expressions required by the Stanislavski system. The slow grandiose gestures in the Wayang Orang or the hand movement in Randai before a character utters a line are not realistic.

Indonesian actors need to learn a new suitable acting method or a modification of the old ones. First, it will make them more "real" and help forge more immediate connections with the audience. Second, it will help them utter dramatic language realistically, as if they use it often in everyday life, even when delivering lengthy monologs. Third, the introduction of the new method will help the traditional theater (such as Randai from West Sumatra or Dul Muluk from Palembang, Si Gale-Gale from North Sumatra, and Wayang Orang from Java), become more accessible for all Indonesians to enjoy, perhaps adding to their cultural preservation.

\section{Step to Move Forward}

\section{Improving and Implementing Indonesia's Cultural Policy}

Based on the UNESCO report from the main objectives on national development for culture in Indonesia (2016). First, the idea of creating an independent ministry for cultural development in Indonesia has never crossed the government's mind. The complex and diverse artistic expressions in Indonesia are difficult to manage if combined with the Ministry of Education on the one hand, and the Ministry of Tourism on the other. Furthermore, I don't know if this is a blessing in disguise or a curse when two departments manage a policy. If there is a Ministry of Culture, the government will be able to ensure the balance of rights among all ethnic groups and, therefore, sustain national integration. Second, like the French Cultural Policy, Indonesia should strive to maintain and protect its identity through the promotion and protection of the arts. The French emphasize promoting and protecting the visual, plastic, theatrical, musical, dance, architectural, literary, televisual, and cinematographic. It is the best way to communicate Indonesia to the world. It is also the best vehicle to unify the Indonesian people. Historically, the number one aims of the French Cultural Policy is the adoption of French as the national language. Indonesia has done the same for the people to use Bahasa Indonesia as their sole language. Therefore, it should also be implemented in the translation of its traditional arts to a more modern interpretation.

The goal of the Indonesian people-as reflected in Article 28.C.1 of the 1945 Constitution and the national motto of "Bhinneka Tunggal Ika," meaning "Unity in Diversity," the unifying entity for this purpose-is the establishment of the Ministry of Culture. It can oversee the problems of implementing the many challenges the county encountered as stated by the UNESCO 2016 report on the Cultural Policy Convention in 2005.

Which are: (1) Most participants have no clues about the content and resolution made during the 2005 Convention. They don't understand what areas/sectors covered under it; (2) In general, all stakeholders, especially the policy makes, have no knowledge of the full potential role of culture and the diversity of cultural expression in specific, towards sustainable development; (3) The continuous changes of the government structure, specifically in the ministerial level, makes it difficult to sustain the planning process; (4) No statistical data available to create relevant cultural policies for the creative industries; (5) Opportunities to present cultural expressions are limited because of insufficient funds; (5) Funding for the arts are 
allocated preferentially; (6) No support is given to minority groups such as youth, women, and indigenous people.

These challenges cannot be overcome by the establishment of the Coordinating Ministry, such as the Ministry of Tourism and Creative Economy or by combining the Ministry of Education with Culture. Since both Ministries face many challenges, notably, infrastructure, it would be unfair for them to handle the diverse challenges created by the Indonesian Culture.

Funding is the most problematic area of developing the arts in Indonesia. The UNESCO report mentioned: "lack of fair financial compensation for the use of traditional cultural expressions." The United States established an independent federal agency, the National Endowment for the Arts (NEA) to finance the arts. Its mission is "to provide funds, promotes, and strengthens the creative capacity of our communities by providing all Americans with diverse opportunities for arts participation." The NEA has made its mark on the world stage, participating in many award-winning projects.

One of its projects titled "Only Connect: Bridging the Urban-Rural Divide through Theater" (2019) is worth mentioning. Paulette Beete, in her article in the NEA ARTS Magazine, covers a touring theater project by the Shakespeare Festival St. Louis. Through its Shakespeare in the Streets program, supported by the National Endowment for the Arts, the organization works to heal the wounds of social disconnection and alienation caused by racial, economic, geographical, and other barriers.

The project, according to Beete, is simple: adapting Shakespeare plays to create a connection. First, the Shakespeare Festival St. Louis identifies the neighborhood in which the company wants to work; they build a relationship with a partnering organization in that location. They include the mayor's office, the libraries, and several community non-profits. Subsequently, with the help of the project partner, a team of artists put together by the Shakespeare Festival deploys to the chosen neighborhood over 12 to 18 months and fosters connections with community members through interviews, story circles, workshops, and other relationship-building activities. The artistic team does anything they can to get close to and start trying to understand the people who live and work there. The goal is to gather the residents' own stories about where their live, their impressions, their hopes, and their fears.
After the initial research phase, a playwright working with the Shakespeare Festival St. Louis takes the lead in adopting one of Shakespeare's plays to tell the story of the community. The final script, as the Shakespeare Festival St. Louis Executive Director Tom Ridgely described, "draws from both Shakespeare's text, texts generated by the community, and the playwright's original creation." No matter how distinct the communities, whether they are a city or a farming community, a connection could always be made through the arts.

As mentioned above, the Shakespeare Festival St. Louis is no different than the community theater group, the Sanggar. Sanggar is the most available community theater to connect the neighboring communities within the big and small islands of Indonesia. Therefore, maybe Indonesia should have its funding entity to create "Unity in Diversity."

\section{Developing and Managing Spesific Infrastructure for the Arts}

The next challenge in the development of Indonesian arts is infrastructure. Buildings, rehearsal rooms, stage, performance space, and equipment-education infrastructure- are essential elements of learning environments. There is much valid evidence that high-quality support facilitates better learning, improves instructional outcomes, and builds enthusiasm, among other benefits (the establishment of 13 cultural parks as new creative spaces in Indonesia is one of them). In Jakarta, for example, the poorly managed sanggar sometimes must rehearse in the garage or an empty car park, which are unfortunately dirty and hot. Attention to the sanggar should be prioritized to create steady growth in the development of new cultural expressions in Indonesia (Teixeira, Amoroso, \& Gresham, 2017).

There are two types of performance spaces provided by the government: First, the professional buildings and productions, which are mostly in Jakarta. Since Jakarta is the capital of Indonesia, most artists consider Jakarta as the place for them to be recognized. Moreover, most artists from Jakarta use these performance spaces, and many regional theater groups who want to tour the capital city must arrange their tours long in advance. Their chances are only to perform two to three nights at the most. In addition, Jakarta is too centralized a place for remote provinces to showcase their works. 
However, the idea that you can only be recognized if performing in Jakarta, and that the regional theater is not a place to showcase your works, has been ingrained in the stakeholder's mind. As the UNESCO's report stated: "Attentions are only given to Java and Sumatra."

Second, the amateur spaces spread-out allover Indonesia are provided by the government the sanggar to perform, which are called The Taman Budaya (the Cultural Park). Most provinces in Indonesia own at least one cultural park where they have small buildings for rehearsal and theaters, both indoors and outdoors. Nevertheless, sanggar are seldom performed at this cultural park. The park might let them rehearse on the outdoor space or the car park, but the theater buildings are mostly rented for wedding ceremonies.

As far as the government is concerned, they might argue that they have provided enough support for the arts in Indonesia to grow at least for the policy and infrastructure. However, according to UNESCO's report on the 2016 Cultural Convention, Indonesia still encountered the same challenges as in the 2005 Convention. Of all the challenges stated in the reports, four stand out: lack of awareness, lack of understanding, lack of shared knowledge, and lack of recognition. These are challenges created by the inability of the people who implemented the result of the 2005 Convention. Cultural Policy is a science, and therefore, should be dealt with as such. There must be a way to unify the diverse cultural expressions in Indonesia, and the ones who unite it should be experts on the subject.

\section{Creating a New Acting Method or Reconsidering the Pre-Existing Ones}

After the creation of sound Indonesian Cultural Policy and the development of better infrastructure, we can shift our attention to develop a new method of understanding the western approaches to the arts or perfecting the pre-existing ones. First, the art schools should be persuaded to revisit their curriculum. In these schools, the curriculum is not geared toward a specific art, such as acting, but mostly for general practitioners, for example, theater practitioners. Furthermore, the government should set up scholarships for visiting theatre experts to teach at these schools. Although the United States established the Fulbright scholarship in Indonesia, the percentage of award for the arts, especially theater, is almost none.
Since our discussion is mostly about performing arts, and notably, theater and acting, the art schools need to reconsider its perception of the Stanislavski system. The old, opposing viewpoints, being in a trance and beside oneself, has no middle ground, and consequently, modern Indonesian theater suffers immensely. The contemporary audience is more critical than the old generation of Indonesians. They won't see performances with actors who are in "trance." Unlike the past generation, modern Indonesians expect truth and demand natural expression from the actors. Thus, if the actors are just "acting," how can the audience believe what happens in the play? How can the audience experience aesthetic emotion when the story event is unreal?

The Stanislavski system taught us to be real on stage so that actors engage with the audience entirely. Unfortunately, most Indonesian actors don't connect and relate to the audience. This disconnection is based on their understanding of the "magic if." Stanislavski said that by living a character's life, understanding their motivation and intentions, experiencing their given circumstances, the actors would magically assume their roles. Hence, Indonesian actors think "becoming the character" means being in a "transcendental" state. They literary forget themselves. To many Indonesian theater practitioners, "magic if" can also mean ostensible. It is only "as though" he or she is the character, hence, the term "beside oneself."

Understanding the Stanislavski system means learning its very basic approach to acting. There are 260 million people living in Indonesia with only seven art schools, and only four have theater departments. It is beyond comprehension that all universities in Indonesia don't incorporate schools of art as part of their curriculum. Thus, most Indonesian actors are self-taught. They learn acting in a sanggar, nonformal community theater groups by rehearsing translated plays, using what little they know of the Stanislavski method. The government faces many problems in maintaining the standard of this poorly managed sanggar. People can create a sanggar without permits from the government or the Department of Education. Moreover, actors/directors in that sanggar have no necessary educational background in acting or directing, and consequently, there are no competency requirements for these actors/directors. The city government commissions art councils to oversee these sanggar but mostly for dance, music, and the fine arts. 
The theater has never been main priority. Recently, however, the new government, led by President, requires sanggar to obtain permits, which will force actors/directors to manage the sanggar properly; it will force them to educate themselves. It is a good enough step forward in making the sanggar a place to revisit the Stanislavski system. Furthermore, the sanggar system is more effective than the art schools in learning the Stanislavski system. First, it is because these theater groups are spread evenly all over Indonesia. Second, the setting is non-formal, meaning one doesn't have to go through a complicated application process to join the group. There are two kinds of sanggar: realistic and non-realistic. As stated above, most nonrealistic sanggar identify themselves with acting as being in a "trance," while the real ones as being "beside oneself." In addition, sanggar is not yet adequately established compare to art schools and, therefore, actors are easily persuaded to change or improve their approach to acting.

Sanggar, arts schools, and universities must work together to help the Indonesian arts, notably the theater, to flourish. In Indonesia, universities that consider the existence of art schools or sanggar are enough to cater to the skills; they don't see that it is necessary for them to be formally involved with the arts. Informally, however, the universities let students create their theater groups as part of the "Unit Kerja Mahasiswa" (UKM) or Student Work Unit. The UKM is a part of their extra-curricular activities. This set up is no different than the sanggar because the students don't get any points or grades for their works in UKM. Moreover, other departments, besides literature, can create their theater groups in the UKM, which are a waste of departmental budget. Therefore, the only feasible solution to the problem is that universities in Indonesia must incorporate the arts into their curriculum.

If the universities are reluctant to incorporate the arts in their educational endeavor, at least they can work on solving the problems of translation through the Literature Department. For example, are we going to translate the classic stories of the Prince Diponegoro into a modern novel or play, using the Javanese language or Indonesia, or a screenplay using Javanese language (with subtitles)? The Indonesian National Library has just acquired plenty of classic stories of legendary Indonesian kings from all over the country and abroad, which are treasures to build the modern Indonesian theater.

Sapardi Djoko Damono is a professor of literature at the Gajah Mada University who has translated many of Ibsen's plays. Although his translations are in formal Bahasa Indonesia, they are the most accurate compared to other adaptations of Ibsen's plays. As we all know, Ibsen is a naturalistic writer, and therefore, his language, although eloquent and poetic, requires informal translation, and consequently, natural expression by the actors. Here is where the art schools come in; they need to include in their proposal ways to apply formal translations, i.e., to educate actors to use official Bahasa Indonesia so that their actions on stage can be realistic and natural. Stanislavski system teaches "living truthfully in imaginary circumstances," and his system teaches how to be yourself, no matter how rigid the translation may be.

Finally, at the very bottom of the totem pole, is the sanggar. This is the best place to apply all that have been created, polished, and regulated by the government though its more refined policy. Now, through their more educated actors/directors, the sanggar will apply the accurate and formal translations created by universities, combined with the newly refined Stanislavski system done by art schools, in their rehearsal and performance. With a more suitable education infrastructure, they will be able to analyze, rehearse, and perform more modern Indonesian or translated plays.

\section{Referensi}

Beete, P. (2019). Only Connect: Bridging the Urban-Rural Divide through Theater. NEA ARTS, 1721.

Shakespeare, W. (1950). Hamlet, Pangeran Denmark (T. Sumardjo, Ed.). Jakarta: Pembangunan.

Stutzin, L. (1989, December). Ancient Drama Given Personal, Contemporary Treatment. The Modesto Bee. 
Teixeira, J., Amoroso, J., \& Gresham, J. (2017). Why Education Infrastructure Matters for Learning. Retrieved from Worldbank website: https://blogs.worldbank.org/education/why-educationinfrastructure-matters-learning

UNESCO. (2016). Indonesia 2016 Report. Retrieved from https://en.unesco.org/creativity/monitoringreporting/periodic-reports/available-reports-30 